\title{
Mutational Dynamics of Aroid Chloroplast Genomes II
}

\author{
Abdullah ${ }^{1 \dagger}$, Claudia L. Henriquez ${ }^{2}$, Thomas B. Croat ${ }^{3}$, Peter Poczai ${ }^{4 *}$ and \\ Ibrar Ahmed ${ }^{5 * \neq}$ \\ ${ }^{1}$ Department of Biochemistry, Faculty of Biological Sciences, Quaid-i-Azam University, Islamabad, Pakistan, ${ }^{2}$ Department \\ of Ecology and Evolutionary Biology, University of California, Los Angeles, Los Angeles, CA, United States, ${ }^{3}$ Missouri \\ Botanical Garden, St. Louis, MO, United States, ${ }^{4}$ Finnish Museum of Natural History, University of Helsinki, Helsinki, Finland, \\ ${ }^{5}$ Alpha Genomics Private Limited, Islamabad, Pakistan
}

OPEN ACCESS

Edited by:

Madhav P. Nepal,

South Dakota State University,

United States

Reviewed by:

Sarbottam Piya,

The University of Tennessee,

Knoxville, United States

Ueric José Borges de Souza,

Federal University of Tocantins, Brazil

${ }^{*}$ Correspondence:

Peter Poczai

peter.poczai@helsinki.fi

Ibrar Ahmed

iaqureshi_qau@yahoo.com

tORCID:

Abdullah

orcid.org/0000-0003-1628-8478

¥These authors have contributed equally to this work

Specialty section:

This article was submitted to Plant Genomics,

a section of the journal

Frontiers in Genetics

Received: 27 September 2020 Accepted: 16 November 2020 Published: 20 January 2021

Citation:

Abdullah, Henriquez CL, Croat TB, Poczai P and Ahmed I (2021) Mutational Dynamics of Aroid

Chloroplast Genomes II.

Front. Genet. 11:610838

doi: 10.3389/fgene.2020.610838
The co-occurrence among single nucleotide polymorphisms (SNPs), insertionsdeletions (InDels), and oligonucleotide repeats has been reported in prokaryote, eukaryote, and chloroplast genomes. Correlations among SNPs, InDels, and repeats have been investigated in the plant family Araceae previously using pair-wise sequence alignments of the chloroplast genomes of two morphotypes of one species, Colocasia esculenta belonging to subfamily Aroideae (crown group), and four species from the subfamily Lemnoideae, a basal group. The family Araceae is a large family comprising 3,645 species in 144 genera, grouped into eight subfamilies. In the current study, we performed 34 comparisons using 27 species from 7 subfamilies of Araceae to determine correlation coefficients among the mutational events at the family, subfamily, and genus levels. We express strength of the correlations as: negligible or very weak (0.10-0.19), weak (0.20-0.29), moderate (0.30-0.39), strong (0.40-0.69), very strong (0.70-0.99), and perfect (1.00). We observed strong/very strong correlations in most comparisons, whereas a few comparisons showed moderate correlations. The average correlation coefficient was recorded as 0.66 between "SNPs and InDels," 0.50 between "InDels and repeats," and 0.42 between "SNPs and repeats." In qualitative analyses, 95-100\% of the repeats at family and sub-family level, while $36-86 \%$ of the repeats at genus level comparisons co-occurred with SNPs in the same bins. Our findings show that such correlations among mutational events exist throughout Araceae and support the hypothesis of distribution of oligonucleotide repeats as a proxy for mutational hotspots.

\section{Keywords: Araceae (aroid), chloroplast genome, correlations, repeats, InDels (insertions/deletions)}

\section{INTRODUCTION}

The chloroplast (cp) is a double-membrane bound organelle in plants, which plays an important role in photosynthesis (Daniell et al., 2016). The chloroplast genome originated from prokaryotes (Palmer, 1985). It shows uniparental inheritance, maternal in most angiosperms and paternal in some gymnosperms (Neale and Sederoff, 1989; Avni and Edelman, 1991). Many mutational events occur in the cp genome, including InDels, SNPs, inversions, tandem repeats, and oligonucleotide repeats (Poczai and Hyvönen, 2011; Jheng et al., 2012; Xu et al., 2015; Abdullah et al., 2019; Iram et al., 2019; Sablok et al., 2019). Sufficient polymorphism and uniparental inheritance make the chloroplast genome suitable for phylogenetic inference, resolution of taxonomic 
discrepancies, population genetics, barcoding, and estimation of time of lineage divergence (Poczai et al., 2011; Ahmed, 2014; Poczai and Hyvönen, 2017; Mehmood et al., 2020c; Shahzadi et al., 2020).

Previously, co-existence of mutations was observed among SNPs, InDels, and repeats in prokaryotic and eukaryotic genomes (Silva and Kondrashov, 2002; Hardison et al., 2003; Tian et al., 2008; Chen et al., 2009; Zhu et al., 2009; McDonald et al., 2011). Three alternate hypotheses were suggested to explain the coexistence of mutations. First, the "regional difference hypothesis" suggests that certain regions are more prone to mutations in comparison to other regions (Silva and Kondrashov, 2002; Hardison et al., 2003). The second, "InDel-induced mutation hypothesis" was suggested based on strong association between InDels and substitutions, which suggested the recruitment of error-prone DNA polymerase at point of InDels is the cause of generation of substitutions (Tian et al., 2008; Yang et al., 2009). The third hypothesis suggests high frequency of oligonucleotide repeats in a region of the genome generates InDels and substitutions (McDonald et al., 2011). To repair DNA damage, the existence of a high number of repeats in a region leads to the recruitment of error-prone DNA polymerases, thus the adjacent sequences replicate with a higher error rate compared to other regions (McDonald et al., 2011). Hence, instead of InDel per se, this hypothesis places more importance on "regional difference hypothesis."

Associations have been reported between SNPs, repeats, InDels, and inversions (Mes et al., 2000; Lockhart et al., 2001; $\mathrm{Li}$ J. et al., 2018). The role of repeats in the generation of inversions (Kim and Lee, 2005; Whitlock et al., 2010) and InDels (Kawata et al., 1997) has also been reported. However, these observations were made on the bases of few loci instead of complete chloroplast genomes. The first study of associations among SNPs, InDels, and repeats based on genome-wide analyses of complete chloroplast genomes included five species of Araceae (Ahmed et al., 2012). That study suggests the distribution of oligonucleotide repeats could be used as a proxy for mutational hotspots. Following Ahmed et al. (2012), correlations were studied in two species of genus Cephalotaxus Siebold \& Zucc. ex Endl. (Yi et al., 2013). However, authors observed very weak correlations between "InDels and SNPs" and "repeats and InDels," whereas moderate correlation was observed between "substitutions and repeats." Recently, strong correlations were reported among these mutational events in the species of genus Dendrobium Sw. (Li et al., 2020), whereas others have described weak to strong correlations in species of the plant family Malvaceae (Abdullah et al., 2020c,d). Hence, the very thorough study by Abdullah and colleagues reported correlations at the family, subfamily, and genus levels among 19 species belonging to seven subfamilies of Malvaceae (Abdullah et al., 2020c).

The previous study of family Araceae was limited to five species of Araceae, including Colocasia esculenta (L.) Schott from subfamily Aroideae, which is a younger clade evolutionarily; and four species from subfamily Lemnoideae, which is among the earliest diverging aroid subfamilies (Nauheimer et al., 2012). Colocasia esculenta is found in tropical habitat and produces unisexual flowers, whereas the four species of subfamily
Lemnoideae produce bisexual flowers and inhabit aquatic habitat (Mayo et al., 1997; Cusimano et al., 2011). These species also demonstrated a different rate of mutations, which is consistent with the finding that aquatic and tropical plant have diverse mutation rates (Abbasi et al., 2016; Hu et al., 2017; Hart et al., 2019; Wang et al., 2020). Sampling is therefore sparse in the previous study for a large and ancient monocot family like Araceae, which dates back to the Early Cretaceous period, and is divided into eight diverse subfamilies distributed across the multitude of ecological habitats (Cusimano et al., 2011; Nauheimer et al., 2012; Henriquez et al., 2014). This family comprises 144 genera and 3,645 species (Boyce and Croat, 2018). Recently, with the advancement of next generation sequencing, chloroplast genome sequences of several species of Araceae were reported from subfamilies Aroideae, Lasioideae, Pothoideae, Monsteroideae, Orontioideae, and Zamioculcadoideae (Han et al., 2016; Choi et al., 2017; Kim et al., 2019; Abdullah et al., 2020a,b; Henriquez et al., 2020a,b). We included 27 species from 7 subfamilies of Araceae which are diverse in term of habit, habitat, native range, and evolutionary time of divergence (Table 1 and Figure 1A). The availability of these genomic resources from a wide array of aroid species (Table 1) provided enough data to elucidate correlations among substitutions, InDels, and repeats throughout the family.

In the current study, we are interested in determining correlations among these mutational events throughout the family Araceae using genus-, subfamily-, and family-level comparisons, aka time of divergences ranged from relatively recent splits to deep divergences. This study will be helpful to understand whether such correlations exist among these five species used in Ahmed et al. (2012) by chance or whether these correlations exist among species of Araceae at varying taxonomic levels and diverse ecological habitats.

\section{MATERIALS AND METHODS}

We downloaded chloroplast genome sequences of 27 species of Araceae from GenBank of the National Center for Biotechnology Information (Table 1). The species are high diverse in terms of habitat, geographical distribution, ecology, and evolutionary history. The species included in the comparisons range in distribution from tropical and subtropical to temperate regions of the world, such as America, Asia, and Africa (Table 1). Similarly, these species also differed in terms of habit and habitat occupying aquatic and semi-aquatic to tropical and subtropical forests (Table 1). The sub-families diverged during Cretaceous to Miocene periods (Nauheimer et al., 2012). We selected one species per genus from all subfamilies other than subfamily Aroideae for family level comparisons. From subfamily Aroideae, we selected 9 species from the comparisons among the major clades using a previous phylogenetic inference of Araceae (Cusimano et al., 2011; Henriquez et al., 2014). We performed comparisons at the family, subfamily, and genus levels. At the family level, all the species were pairwise compared with Orontium aquaticum L. (Orontioideae) which is among the basal groups of Araceae following a previous approach applied in 
TABLE 1 | GenBank accession numbers of the species used in comparative analyses along with native range, habit and habitat of each species.

\begin{tabular}{|c|c|c|c|c|c|}
\hline S. No & Species & NCBI accession & Subfamily & Native range & Habit and habitat \\
\hline 1 & $\begin{array}{l}\text { Orontium } \\
\text { aquaticum }\end{array}$ & MT226773 & Orontioideae & East United States & $\begin{array}{l}\text { Rhizomatous marginal aquatic herb grows in } \\
\text { ponds, streams, and shallow lakes }\end{array}$ \\
\hline 2 & $\begin{array}{l}\text { Symplocarpus } \\
\text { renifolius }\end{array}$ & KY039276 & Orontioideae & $\begin{array}{l}\text { Russian far East to Korea and North \& } \\
\text { Central Japan }\end{array}$ & $\begin{array}{l}\text { Herb growing on wet places, moist mixed and } \\
\text { coniferous forests, forest swamps, swampy } \\
\text { meadows and lands }\end{array}$ \\
\hline 3 & $\begin{array}{l}\text { Symplocarpus } \\
\text { nipponicus }\end{array}$ & MK341566 & Orontioideae & Japan, Korea, Manchuria & Herb growing on wet places \\
\hline 4 & Lasia spinosa & MT226772 & Lasioideae & Tropical and subtropical Asia & $\begin{array}{l}\text { 1-2-m-tall herb. Grow on swamps, riverbanks, } \\
\text { ditches, moist places in tropical and subtropical } \\
\text { forests, sometimes cultivated along fish ponds } \\
\text { and rice fields }\end{array}$ \\
\hline 5 & $\begin{array}{l}\text { Zamioculcas } \\
\text { zamiifolia }\end{array}$ & MT226775 & Zamioculcadoideae & Kenya to KwaZulu-Natal & $\begin{array}{l}\text { Tuber subcylindric, } \pm 3-4 \mathrm{~cm} \text { in diameter or } \\
\text { more, tough or woody. Humid to dry evergreen } \\
\text { forest, Brachystegia woodland, dry wooded } \\
\text { grassland, bushland thicket, often on rocks, } \\
\text { locally abundant }\end{array}$ \\
\hline 6 & $\begin{array}{l}\text { Stylochaeton } \\
\text { bogneri }\end{array}$ & MT226774 & Zamioculcadoideae & East Tropical Africa & $\begin{array}{l}\text { Rhizome slender, horizontal, elongated } \\
0.4-0.6 \mathrm{~cm} \text {. Evergreen forest, Brachystegia } \\
\text { woodland }\end{array}$ \\
\hline 7 & Lemna minor & DQ400350 & Lemnoideae & $\begin{array}{l}\text { North and Central America, Temperate } \\
\text { and Subtropical Old World }\end{array}$ & Free-floating aquatic \\
\hline 8 & Spirodela polyrhiza & JN160603 & Lemnoideae & Cosmopolitan & $\begin{array}{l}\text { Floating herbs in form of colonies which cover } \\
\text { large area of water }\end{array}$ \\
\hline 9 & Wolffiella lingulata & JN160604 & Lemnoideae & Tropical and Subtropical America & Aquatic herb \\
\hline 10 & Wolffia australiana & JN160605 & Lemnoideae & $\begin{array}{l}\text { South and South East Australia, } \\
\text { New Zealand }\end{array}$ & Aquatic herb \\
\hline 11 & $\begin{array}{l}\text { Spathiphyllum } \\
\text { kochii }\end{array}$ & KR270822 & Monsteroideae & Colombia to Venezuela & $\begin{array}{l}\text { Herb exist on Lowland to middle-elevation } \\
\text { forests }\end{array}$ \\
\hline 12 & $\begin{array}{l}\text { Epipremnum } \\
\text { aureum }\end{array}$ & NC_027954 & Monsteroideae & Society Islands (Moorea) & Small herb exists on wet hill forest. ca 500 m \\
\hline 13 & Monstera adansonii & MN046888 & Monsteroideae & South Mexico to Tropical America & $\begin{array}{l}\text { Herb, creeper or hemiepiphyte ranged in size } \\
\text { from } 2 \text { to } 4 \mathrm{~m} \text { climbing on the tree in dense rain } \\
\text { forest }\end{array}$ \\
\hline 14 & $\begin{array}{l}\text { Stenospermation } \\
\text { multiovulatum }\end{array}$ & MN046893 & Monsteroideae & West Colombia to Ecuador & Epiphyte herb \\
\hline 15 & $\begin{array}{l}\text { Spathiphyllum } \\
\text { patulinervum }\end{array}$ & MN046890 & Monsteroideae & Tropical region of the America & Evergreen herb \\
\hline 16 & $\begin{array}{l}\text { Anthurium } \\
\text { huixtlense }\end{array}$ & MN996266 & Pothoideae & Mexico to Central America & $\begin{array}{l}\text { Terrestrial or epiphytic, stem ranged to } 14 \mathrm{~cm} \\
\text { long }\end{array}$ \\
\hline 17 & Pinellia ternata & KR270823 & Aroideae & China to Temperate East Asia & $\begin{array}{l}\text { Small herb grows on grasslands, cultivated } \\
\text { lands, secondary forests, wastelands, }\end{array}$ \\
\hline 18 & $\begin{array}{l}\text { Colocasia } \\
\text { esculenta }\end{array}$ & JN105689 & Aroideae & India to South China and Sumatera & $\begin{array}{l}\text { Robust, acaulescent herb to } 2 \text { m. Wild forms } \\
\text { occur as colonies on river banks, in open } \\
\text { swampy places, on slopes and on rocks and } \\
\text { banks in the splash-zone of waterfalls. Very } \\
\text { occasionally found in forest under story. Widely } \\
\text { cultivated usually near farmhouses or in water } \\
\text { fields; also naturalized or perhaps native in wet } \\
\text { places in forests, valleys, swamps, wastelands, } \\
\text { and at watersides }\end{array}$ \\
\hline 19 & Arisaema ringens & MK111107 & Aroideae & $\begin{array}{l}\text { East China, South Korea, Central Japan } \\
\text { to Taiwan }\end{array}$ & $\begin{array}{l}\text { Herbaceous perennial with height of } 1-1.5 \text { feet. } \\
\text { Grow on humus-rich, moist but well-drained } \\
\text { soils in part shade to full shade. Needs } \\
\text { consistent moisture and does poorly in heavy } \\
\text { clay soils. }\end{array}$ \\
\hline 20 & $\begin{array}{l}\text { Anubias } \\
\text { heterophylla }\end{array}$ & MN046884 & Aroideae & West Central Tropical Africa, Angola & $\begin{array}{l}\text { Rhizome creeping, prostrate and rooting, } \\
\text { growing on rocky grounds on the banks of or in } \\
\text { water courses, and on shady places in the } \\
\text { forest }\end{array}$ \\
\hline 21 & $\begin{array}{l}\text { Arisaema } \\
\text { franchetianum }\end{array}$ & MN046885 & Aroideae & South China to North Indo-China & $\begin{array}{l}\text { Dioecious plant of up to } 1.5 \text { feet, grow in } \\
\text { Forests, thickets, and grasslands }\end{array}$ \\
\hline
\end{tabular}


TABLE 1 | Continued

\begin{tabular}{|c|c|c|c|c|c|}
\hline S. No & Species & NCBI accession & Subfamily & Native range & Habit and habitat \\
\hline 23 & $\begin{array}{l}\text { Taccarum } \\
\text { caudatum }\end{array}$ & MN046895 & Aroideae & Brazil to Bolivia & Deciduous herbs, grow in rocky area \\
\hline 24 & $\begin{array}{l}\text { Montrichardia } \\
\text { arborescens }\end{array}$ & MN046889 & Aroideae & Tropical America & Aquatic herb \\
\hline 26 & $\begin{array}{l}\text { Syngonium } \\
\text { angustatum }\end{array}$ & MN046894 & Aroideae & Mexico to Colombia & Climbing herb \\
\hline 27 & $\begin{array}{l}\text { Amorphophallus } \\
\text { konjac }\end{array}$ & MK611803 & Aroideae & China & $\begin{array}{l}\text { Tuber brown, slightly glossy, depressed } \\
\text { globose, to ca. } 20 \mathrm{~cm} \text { high, to ca. } 30 \mathrm{~cm} \text { in } \\
\text { diam., seasonally producing numerous long } \\
\text { rhizomatous offsets with swollen apical part, } \\
\text { these to ca. } 50 \times 3 \mathrm{~cm} \text {. Open situations or } \\
\text { forest margins and thickets, secondary forests }\end{array}$ \\
\hline
\end{tabular}

The data of distributions, habit and habitat are taken from powo.science.kew.org and Mayo et al. (1997).
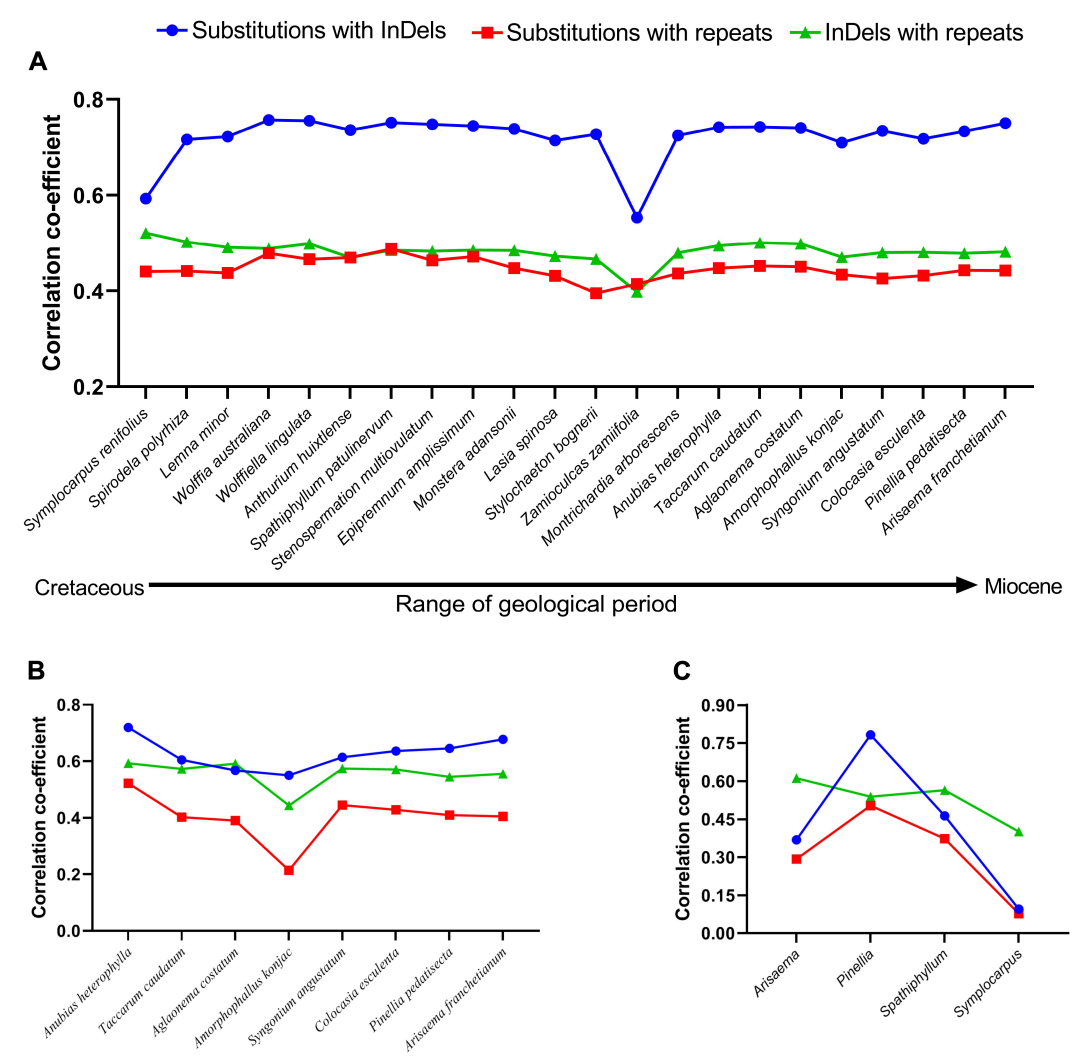

FIGURE 1 | Coefficient of correlations were determined among mutational events using pairwise alignments. (A) Family-level comparisons, (B) subfamily-level comparisons in Aroideae, (C) Genus-level comparisons. Orontium aquaticum was used as reference at family level, Montrichardia arborescence was used as reference at subfamily level, and at the generic level, Arisaema franchetianum, Pinellia pedatisecta, Spathiphyllum patulinervum, and Symplocarpus renifolius were used as references for Arisaema ringens, Pinellia ternata, Spathiphyllum kochii, and Symplocarpus nipponicus, respectively.

family Malvaceae (Abdullah et al., 2020c). At the subfamily level in Aroideae, the genome of Montrichardia arborescens (L.) Schott is used as a reference for the other species of subfamily Aroideae.
At the generic level, Arisaema franchetianum Engler, Pinellia pedatisecta Schott, Spathiphyllum patulinervum G. S. Bunting, and Symplocarpus renifolius Schott ex Tzvelev were used as 
references for Arisaema ringens (Thunb.) Schott, Pinellia ternata (Thunb.) Makino, Spathiphyllum kochii Engl. \& K. Krause, and Symplocarpus nipponicus Makino, respectively.

The MAFFT (Multiple alignment using fast Fourier transform) integrated in Geneious R8.1 (Kearse et al., 2012) was used for the pairwise alignment in all comparisons after removal of long inverted repeat regions following Ahmed et al. (2012). We also deleted $y c f 1$ and $r p s 15$ genes along with intergenic-spacer regions, as these genes jump between small single-copy and inverted-repeat regions, hence present the problem of rate heterotachy (Lockhart et al., 2006; Abdullah et al., 2020a). Each alignment was divided into non-overlapping bins of $250 \mathrm{bp}$ and deletions in the reference genome were removed from the alignment after noting their positions. This approach has been used previously (Ahmed et al., 2012; Yi et al., 2013; Abdullah et al., 2020c) to fix the coordinates positions in the reference genomes for allocations of oligonucleotide repeats. The InDels were counted manually and assigned into bins of $250 \mathrm{bp}$. The forward and reverse repeats were determined as $\geq 14$ bp using REPuter (Kurtz et al., 2001) by searching for 5,000 repeats in the reference genomes at family, subfamily, and generic levels. The names of the species whose cp genomes were used as reference are mentioned above (vide infra). All the repeats with exact match located at least $10 \mathrm{bp}$ away from each other were included in the analyses after excluding redundant repeats. The repeats were allocated into bins using Microsoft Excel (Redmond, United States). The numbers of substitutions were determined by a custom Pearl script and allocated into bins in Microsoft Excel.

Quantitative and qualitative approaches were used to determine the correlations among the mutational events. The normality test was first performed on the data in Minitab v.19 following Abdullah et al. (2020c). This test confirmed the non-normal distribution of mutational events (Supplementary Figures S1-S4). Hence, Spearman rho ( $\rho)$ correlations were applied on the non-normal data in Minitab v.19. The methodology described in Akoglu (2018) was used to express strength of the correlations as follows: negligible or very weak (0.10-0.19), weak (0.20-0.29), moderate (0.30-0.39), strong (0.40-0.69), very strong (0.70-0.99), and perfect (1.00). The probability $(p)$ of significance of correlations was determined at $0.05 \alpha$ level.

In the qualitative approach, we evaluated the co-occurrence of InDels with substitutions, and of repeats with InDels and substitutions following Abdullah et al. (2020c).

\section{RESULTS}

\section{Correlations Among SNPs, InDels, and Oligonucleotide Repeats at the Family Level}

Among 22 comparisons at the family level, the correlations between SNPs and InDels were strong for Symplocarpus renifolius and Zamioculcas zamiifolia (Lodd.) Engl., whereas were categorized as very strong in the remaining 20 comparisons (Figure 1A). Correlations between SNPs and repeats were regarded as strong for all other comparisons except Stylochaeton bogneri Mayo, which showed moderate correlations (Figure 1A). We recorded strong correlations between repeats and InDels in all comparisons. The average values of coefficients of correlations were recorded highest between substitutions and InDels (0.72), followed by InDels and repeats (0.48), and then by substitutions and repeats (0.44). All correlations were observed with a high significance of $p<0.0001$. All the comparisons showed high similarities in correlations from basal groups to the crown group. The distributions of substitutions, InDels, and repeats in $250 \mathrm{bp}$ bins are shown in Supplementary Table S1.

\section{Correlations Among SNPs, InDels, and Oligonucleotide Repeats at the Subfamily Level}

For eight comparisons within the subfamily Aroideae, strong correlations were observed among SNPs and InDels for seven comparisons, whereas a very strong correlation was observed for Anubias heterophylla Engl. (Figure 1B). We recorded strong correlations between SNPs and repeats for six comparisons, whilst moderate correlation was recorded for Aglaonema costatum N.E.Br., and weak correlation was recorded in Amorphophallus konjac K. Koch (Figure 1B). We observed strong correlations between InDels and repeats for all comparisons (Figure 1B). The average values of correlation coefficients showed a similar pattern as observed at the familylevel comparisons: it remained highest between substitutions and InDels (0.62), followed by InDels and repeats (0.55), and then by substitutions and repeats (0.40). All correlations at the subfamily level were also observed with high significance of $p<0.0001$. The distributions of substitutions, InDels, and repeats in 250 bp bins are shown in Supplementary Table S2.

\section{Correlations Among SNPs, InDels, and Oligonucleotide Repeats at the Genus Level}

We investigated interspecific correlations in four genera as representative of recent splits between species belonging to the same genera. The correlation coefficients greatly varied in these comparisons; the correlations between SNPs and InDels remained very strong between the species of genus Pinellia Ten., strong in Spathiphyllum Schott, moderate in Arisaema Mart., and negligible in Symplocarpus Salisb. (Figure 1C). The same pattern was evident for correlations between substitutions and repeats, which remained strong in Pinellia, moderate in Spathiphyllum, weak in Arisaema, and negligible in Symplocarpus (Figure 1C). Conversely, all comparisons showed strong correlations between repeats and InDels (Figure 1C). In these comparisons, the average values of the coefficients of correlations were found highest between repeats and InDels (0.52), followed by SNPs and InDels (0.42), and SNPs and repeats (0.31). Except Symplocarpus, correlations in all other comparisons were observed with $p<0.0001$. Low significance was observed for substitutions and InDels $(p=0.024)$, and for substitutions and repeats $(p=0.055)$ in Symplocarpus. The distributions of substitutions, InDels, and repeats in 250 bp bins are shown in Supplementary Table S3. 


\section{Qualitative Analyses of the Existence of InDels With Substitutions, and of Repeats With Substitutions and InDels}

In the qualitative analyses, we determined the percentages of the InDel-containing bins that co-occurred with SNPs, and of the repeat-containing bins that co-occurred with InDels and SNPs. At the family level, we observed that up to $99.47-100 \%$ of InDelcontaining bins also contained SNPs, 97.88-100\% of repeatcontaining bins also showed SNPs, and up to $66.45-80.51 \%$ of repeat-containing bins also contained InDels (Table 2).

The results at the subfamily level show high similarities with the family level. We observed $97.98-100 \%$ of InDelcontaining bins that also contained SNPs, $94.95-100 \%$ of repeatcontaining bins also contained SNPs, whereas up to $60.73-80 \%$ of repeat-containing bins also exhibited InDels (Table 2). In genus-level comparisons, for qualitative comparisons of three among the four genera, 71.08-90.55\% of InDel-containing bins exhibited SNPs, $42.66-75.16 \%$ of repeat-containing bins also contained InDels, while $36-86.51 \%$ of the repeat-containing bins also displayed SNPs. The genus Symplocarpus remained an exception, for which only $23.73 \%$ of InDel-containing bins showed SNPs, and only $20.28 \%$ of repeat-containing bins exhibited InDels, while merely $15.66 \%$ of repeat-containing bins displayed SNPs (Table 2).

\section{Distributions of InDels and Substitutions at Family, Subfamily, and Genus Level}

At the family level, the distantly related species showed existence of a high number of substitutions and InDels with 3,430-15,459 substitutions and 456-1,156 InDels. Most of the substitutions and

TABLE 2 | The co-occurrence of InDels with substitutions, and of repeats with substitutions and InDels in family Araceae.

\begin{tabular}{|c|c|c|c|}
\hline Species & SNPs with InDels (\%) & InDels with repeats (\%) & SNPs with repe \\
\hline \multicolumn{4}{|l|}{ Family level } \\
\hline Aglaonema costatum & 100 & 76.69 & 99.57 \\
\hline Amorphophallus konjac & 100 & 75.00 & 100 \\
\hline Anthurium huixtlense & 100 & 77.11 & 99.57 \\
\hline Anubias heterophylla & 100 & 75.00 & 99.57 \\
\hline Arisaema franchetianum & 100 & 75.85 & 100 \\
\hline Colocasia esculenta & 100 & 76.27 & 100 \\
\hline Epipremnum amplissimum & 100 & 77.00 & 100 \\
\hline Lasia spinosa & 100 & 76.69 & 99.57 \\
\hline Lemna minor & 100 & 78.72 & 100 \\
\hline Monstera adansonii & 100 & 77.11 & 100 \\
\hline Montrichardia arborescens & 100 & 74.57 & 99.57 \\
\hline Pinellia pedatisecta & 100 & 75.00 & 99.57 \\
\hline Spathiphyllum patulinervum & 100 & 76.69 & 100 \\
\hline Spirodela polyrhiza & 100 & 78.39 & 100 \\
\hline Stenospermation multiovulatum & 100 & 76.69 & 100 \\
\hline Stylochaeton bogneri & 100 & 76.69 & 97.88 \\
\hline Symplocarpus renifolius & 99.47 & 64.45 & 99.57 \\
\hline Syngonium angustatum & 100 & 74.58 & 99.57 \\
\hline Taccarum caudatum & 100 & 76.27 & 99.57 \\
\hline Wolffia australiana & 100 & 80.51 & 100 \\
\hline Wolffiella lingulata & 100 & 80.10 & 100 \\
\hline Zamioculcas zamiifolia & 99.63 & 80.50 & 99.57 \\
\hline \multicolumn{4}{|l|}{ Subfamily level } \\
\hline Aglaonema costatum & 100 & 66.00 & 98.66 \\
\hline Amorphophallus konjac & 99.57 & 63.75 & 94.95 \\
\hline Anubias heterophylla & 97.98 & 60.73 & 97.98 \\
\hline Arisaema franchetianum & 100 & 79.80 & 98.99 \\
\hline Colocasia esculenta & 100 & 67.11 & 100 \\
\hline Pinellia pedatisecta & 99.57 & 66.10 & 98.66 \\
\hline Syngonium angustatum & 100 & 64.76 & 99.33 \\
\hline Taccarum caudatum & 100 & 66.10 & 99.33 \\
\hline \multicolumn{4}{|l|}{ Genus level } \\
\hline Arisaema & 85.71 & 75.16 & 81.36 \\
\hline Pinellia & 71.08 & 42.66 & 36.00 \\
\hline Spathiphyllum & 90.55 & 64.18 & 86.51 \\
\hline Symplocarpus & 23.73 & 20.28 & 15.66 \\
\hline
\end{tabular}


InDels were found in aquatic species of subfamily Lemnoideae (Table 3). At the subfamily level, deeply diverge species showed 3,639-5,859 substitutions and 537-765 InDels. At the genus level, 89-1,793 substitutions and 70-352 InDels were determined in closely related species (Table 3). The species of genus Symplocarpus show a low number of substitutions and InDels 89 and 70 , respectively.

\section{DISCUSSION}

We determined the extent of correlations among SNPs, InDels, and repeats in cp genomes using 27 species from 23 genera, distributed among seven of the eight subfamilies of Araceae. We

TABLE 3 | Distribution of SNPs and InDels at family, subfamily, and genus level.

\begin{tabular}{|c|c|c|}
\hline Species & SNPs & InDels \\
\hline \multicolumn{3}{|l|}{ Family level } \\
\hline Aglaonema costatum & 9,283 & 991 \\
\hline Amorphophallus konjac & 9,849 & 956 \\
\hline Anthurium huixtlense & 10,533 & 1,007 \\
\hline Anubias heterophylla & 9,283 & 957 \\
\hline Arisaema franchetianum & 10,343 & 1,006 \\
\hline Colocasia esculenta & 9,819 & 950 \\
\hline Epipremnum amplissimum & 9,826 & 989 \\
\hline Lasia spinosa & 10,193 & 1,019 \\
\hline Lemna minor & 13,424 & 1,060 \\
\hline Monstera adansonii & 9,736 & 979 \\
\hline Montrichardia arborescens & 9,248 & 922 \\
\hline Pinellia pedatisecta & 10,190 & 964 \\
\hline Spathiphyllum patulinervum & 10,003 & 971 \\
\hline Spirodela polyrhiza & 11,624 & 1003 \\
\hline Stenospermation multiovulatum & 9,701 & 959 \\
\hline Stylochaeton bogneri & 9,783 & 1,005 \\
\hline Symplocarpus renifolius & 3,430 & 456 \\
\hline Syngonium angustatum & 9,682 & 977 \\
\hline Taccarum caudatum & 9,712 & 964 \\
\hline Wolffia australiana & 15,459 & 1,147 \\
\hline Wolffiella lingulata & 15,238 & 1,156 \\
\hline Zamioculcas zamiifolia & 9,336 & 958 \\
\hline \multicolumn{3}{|l|}{ Subfamily Aroideae level } \\
\hline Aglaonema costatum & 3,639 & 571 \\
\hline Amorphophallus konjac & 3,750 & 549 \\
\hline Anubias heterophylla & 5,859 & 537 \\
\hline Arisaema franchetianum & 5,592 & 765 \\
\hline Colocasia esculenta & 4,704 & 638 \\
\hline Pinellia pedatisecta & 5,161 & 707 \\
\hline Syngonium angustatum & 4,308 & 620 \\
\hline Taccarum caudatum & 4,061 & 628 \\
\hline \multicolumn{3}{|l|}{ Genus level } \\
\hline Arisaema ringens vs. Arisaema franchetianum & 1,355 & 303 \\
\hline Pinellia ternata vs. Pinellia pedatisecta & 1,793 & 173 \\
\hline Spathiphyllum kochii vs. Spathiphyllum patulinervum & 1,662 & 352 \\
\hline Symplocarpus nipponicus VS Symplocarpus renifolius & 89 & 70 \\
\hline
\end{tabular}

performed 34 pairwise comparisons and observed strong/verystrong correlations for most of the comparisons among these mutational events, which suggests high associations between these mutational events.

We removed the $y c f 1$ and $r p s 15$ genes, along with intergenic spacer regions, as these elements are located at the single-copy and inverted-repeat junctions-appearing in single-copy regions in some species, and in inverted repeats regions in others. Singlecopy regions undergo a different rate of mutation compared to the inverted-repeat regions, hence the same genes that occur in single-copy regions in some species and in inverted-repeats in other species undergo a phenomenon known as rate heterotachy (Lockhart et al., 2006). We previously reported the effect of rate heterotachy in Araceae (Abdullah et al., 2020a). Single nucleotide polymorphisms, InDels, and oligonucleotide repeats did not follow the normal distribution curves in normality tests using Minitab v.19. These observations are in agreement with previous reports of chloroplast genomes in which certain regions were found to be predisposed to mutations and reported as hotspots for mutations (Ahmed et al., 2013; Li Y. et al., 2018; Sablok et al., 2019; Abdullah et al., 2020e; Mehmood et al., 2020a,b).

Ahmed et al. (2012) determined correlations among SNPs, InDels, and repeats using chloroplast genomes of two morphotypes of one species, C. esculenta, and four species of the subfamily Lemnoideae, including Lemna minor L., Wolffia australiana (Benth.) Hartlog \& Plas, Wolffiella lingulata Hegelm., and Spirodela polyrhiza (L.) Schleid. Colocasia esculenta is tropical and belongs to the crown group, whereas the species of Lemnoideae are aquatic and belong to the basal group. Aquatic plants evolve faster as compared to non-aquatic, and tropical plants evolve faster as compared to temperate plants (Abbasi et al., 2016; Hu et al., 2017; Hart et al., 2019; Wang et al., 2020). We found higher rates of mutation in terms of substitutions and InDels in the species of Lemnoideae as compared to other species (Table 3). Hence, further exploration of these observations was required in diverse species to gain insight into correlations among mutational events as sparse sampling of taxa is evident in the previous study of Ahmed et al. (2012). In order to cover the taxa across the family tree, here we include species spanning seven of the eight subfamilies of Araceae and used 34 comparisons among 27 diverse species in terms of habit, habitat, and evolution.

At the family and subfamily levels, most of the comparisons exhibited strong/very strong correlations among "SNPs and InDels," "SNPs and repeats," and "InDels and repeats." Hence, our study confirms strong correlations among mutational events in close comparisons (subfamily level) and distant comparisons (family level). Here, the high similarity among mutational events in diverse species in terms of geography, ecology, and time of divergence (Table $\mathbf{1}$ and Figure 1A) demonstrates that the correlations are unaffected by the geographical distribution, habit, and habitat. Weak correlations in generic-level comparisons, however, may be due to fewer SNPs and InDels in recently diverged species within the same genera. Strong correlations have also been reported in the family Malvaceae (Abdullah et al., 2020c). At the genus 
level, we observed very weak to strong correlations among mutational events. Similar results were reported in the family Malvaceae at the genus level (Abdullah et al., 2020c). Here, very weak correlations were recorded between the species of Symplocarpus. The species of Symplocarpus showed closed resemblance and revealed the presence of few substitutions (89) and InDels (70). Hence, the weak correlations might be due to recent divergence of these species from each other. Similar results were observed in the closely related species of Theobroma L. (Abdullah et al., 2020c) and Cephalotaxus (Yi et al., 2013). Previously, Tian et al. (2008) suggested InDels as mutagens, whereas McDonald et al. (2011) suggested the role of repeats in the generation of InDels and SNPs. However, they considered the recruitment of error-prone DNA polymerases during replication to be the cause of high mutations due to errors in replications. Therefore, in closely related species InDels and repeats might not have enough time to generate substitutions. Moreover, correlations between "InDels and repeats" were found to be higher than correlations between "SNPs and InDels" and "SNPs and repeats" in three out of four comparisons. Similar results were previously observed in family Malvaceae, where four of the five comparisons showed high correlation between "InDels and repeats" as compared to "SNPs and InDels" and "SNPs and repeats" (Abdullah et al., 2020c). These observations at the genus level suggest that most of the InDels are generated by repeats first, and then both InDels and repeats contribute to the generation of SNPs over a period of time.

The quantitative analyses showed very strong correlations between SNPs and InDels in most cases, whereas the qualitative analyses revealed the occurrence of more than $90 \%$ of InDels containing bins with SNPs. Previously strong associations were also observed among SNPs and InDels in prokaryotic, eukaryotic, and chloroplast genomes (Tian et al., 2008; Zhang et al., 2008; Chen et al., 2009; Yang et al., 2009; Abdullah et al., 2020c; Li et al., 2020). The InDels were suggested as a mutagen for the generation of SNPs based on the observation of high association between InDels and SNPs in prokaryotic and eukaryotic genomes (Tian et al., 2008; Zhu et al., 2009). Our analyses lend support to these previous results. Chloroplast genomes originate from prokaryotes and decrease in size by loss of genomic portions along with several genes (Palmer, 1985) but still reveal high associations between SNPs and InDels.

Abdullah et al. (2020c) reported weak to moderate correlations between "SNPs and repeats" and "InDels and repeats" in most of the comparisons in the plant family Malvaceae. However, based on qualitative analyses, they reported the existence of up to $60 \%$ of repeats with InDels and up to $90 \%$ of repeats with SNPs. In the current study, we report strong correlations between "InDels and repeats" and "SNPs and repeats" based on quantitative analyses in the family Araceae, whereas based on qualitative analyses we observed the existence of up to $100 \%$ of repeats with SNPs and up to $80 \%$ of repeats with InDels. The variation in the results might be due to the inclusion of a copy of inverted repeats in comparisons of family Malvaceae as the inverted-repeats region showed less polymorphism due to copy-dependent repair mechanisms (Zhu et al., 2016). Here we excluded one copy of the Inverted repeats from our comparisons, following previous studies (Ahmed et al., 2012; Yi et al., 2013). A high frequency of repeats has previously been considered the cause of generations of SNPs and InDels in the adjacent regions based on strong associations between "InDels and repeats" and "SNPs and repeats" in prokaryotic and eukaryotic genomes (McDonald et al., 2011). Here, our analyses in a wider sampling of species of Araceae and the previous report of Malvaceae (Abdullah et al., 2020c) also support the role of repeats in the generation of InDels and substitutions, and supports the hypothesis that oligonucleotide repeats can be used as a proxy for identification of mutational hotspots (Ahmed et al., 2012; Abdullah et al., 2020c). This hypothesis has practical implications in selecting appropriate loci for comparative analyses. No one single locus is good enough for evolutionary comparisons at all time scales; slow evolving regions should be preferred for deep divergences, while mutational hotspots for the closely related taxa and recently diverged species (Ahmed et al., 2013; Ahmed, 2015; Li et al., 2020). A recent report of Ahmed et al. (2020) on family Araceae showed the practical implication of the use of repeats in identification of suitable polymorphic loci for the study of phylogeography and population genetics. Their developed markers from the identified loci providing new insight about the origin of Colocasia esculenta in southeast Asia instead of Papua New Guinea (Ahmed et al., 2020). Our current results support strong associations between repeats and substitutions and repeats and InDels in Araceae, which can be helpful for identifying species-specific suitable loci for the study of phylogeography, domestication, and population genetics of other species of Araceae.

In conclusion, the previous observations in five aroid species were not an artifact of low sampling but a representative sample of the correlations found at various taxonomic levels, and in ecologically, geographically and evolutionarily of Araceae. The strong associations of InDels with SNPs, and of repeats within InDels and SNPs, support the previous observation (Ahmed et al., 2012) that the multiple hypotheses outlined in the introduction (vide infra) might explain the mutational dynamics of chloroplast genome evolution. The strong associations among the three types of mutational events reported in prokaryotic, eukaryotic (Tian et al., 2008; Zhang et al., 2008; Chen et al., 2009; McDonald et al., 2011), and chloroplast genomes (Ahmed et al., 2012; Abdullah et al., 2020c; Li et al., 2020), show that such co-occurrence of mutations might be a universal phenomenon in all types of genomes. Further studies in prokaryotes and eukaryotes are needed to test this hypothesis.

\section{DATA AVAILABILITY STATEMENT}

Publicly available datasets were analyzed in this study. This data can be found here: All the accession numbers are given in Table $\mathbf{1 .}$ Moreover, result of analyses are also provided in the article or as Supplementary Material. 


\section{AUTHOR CONTRIBUTIONS}

A: data analyses, data interpretation, writing initial draft, and conceptualization. $\mathrm{CH}$ : data analyses, review and editing of initial draft. TC: data interpretation and conceptualization. PP and IA: conceptualization, review, editing of initial draft, and supervision. All authors contributed to the article and approved the submitted version.

\section{SUPPLEMENTARY MATERIAL}

The Supplementary Material for this article can be found online at: https://www.frontiersin.org/articles/10.3389/fgene. 2020.610838/full\#supplementary-material

\section{REFERENCES}

Abbasi, S., Afsharzadeh, S., Saeidi, H., and Triest, L. (2016). Strong genetic differentiation of submerged plant spopulations across mountain ranges: evidence from Potamogeton pectinatus in Iran. PLoS One 11:e0161889. doi: 10.1371/journal.pone.0161889

Abdullah, Henriquez, C. L., Mehmood, F., Carlsen, M. M., Islam, M., and Waheed, M. T. (2020a). Complete chloroplast genomes of Anthurium huixtlense and Pothos scandens (Pothoideae, Araceae): unique inverted repeat expansion and contraction affect rate of evolution. J. Mol. Evol. 2020:987859. doi: 10.1101/ 2020.03.11.987859

Abdullah, Henriquez, C. L., Mehmood, F., Shahzadi, I., Ali, Z., and Waheed, M. T. (2020b). Comparison of chloroplast genomes among species of Unisexual and Bisexual clades of the monocot family Araceae. Plants 9:737. doi: 10.3390/ plants 9060737

Abdullah, Mehmood, F., Shahzadi, I., Ali, Z., Islam, M., and Naeem, M. (2020c). Correlations among oligonucleotide repeats, nucleotide substitutions and insertion-deletion mutations in chloroplast genomes of plant family Malvaceae. J. Syst. Evol. doi: 10.1111/jse.12585

Abdullah, Mehmood, F., Shahzadi, I., Waseem, S., Mirza, B., and Ahmed, I. (2020d). Chloroplast genome of Hibiscus rosa-sinensis (Malvaceae): comparative analyses and identification of mutational hotspots. Genomics 112, 581-591. doi: 10.1016/j.ygeno.2019.04.010

Abdullah, Waseem, S., Mirza, B., Ahmed, I., and Waheed, M. T. (2020e). Comparative analyses of chloroplast genomes of Theobroma cacao and Theobroma grandiflorum. Biologia 75, 761-771. doi: 10.2478/s11756-019-00388-8

Abdullah, Shahzadi, I., Mehmood, F., Ali, Z., Malik, M. S., and Waseem, S. (2019). Comparative analyses of chloroplast genomes among three Firmiana species: identification of mutational hotspots and phylogenetic relationship with other species of Malvaceae. Plant Gene 19:100199. doi: 10.1016/J.PLGENE. 2019.100199

Ahmed, I. (2014). Evolutionary dynamics in Taro. PhD thesis, Available online at: https://mro.massey.ac.nz/handle/10179/5610 (accessed August 5, 2020).

Ahmed, I. (2015). Chloroplast genome sequencing: some reflections. J. Next Gener. Seq. Appl. 2:119. doi: 10.4172/2469-9853.1000119

Ahmed, I., Biggs, P. J., Matthews, P. J., Collins, L. J., Hendy, M. D., and Lockhart, P. J. (2012). Mutational dynamics of aroid chloroplast genomes. Genome Biol. Evol. 4, 1316-1323. doi: 10.1093/gbe/evs110

Ahmed, I., Lockhart, P. J., Agoo, E. M. G., Naing, K. W., Nguyen, D. V., and Medhi, D. K. (2020). Evolutionary origins of taro (Colocasia esculenta) in Southeast Asia. Ecol. Evol. 1-14. doi: 10.1002/ece3.6958

Ahmed, I., Matthews, P. J., Biggs, P. J., Naeem, M., Mclenachan, P. A., and Lockhart, P. J. (2013). Identification of chloroplast genome loci suitable for high-resolution phylogeographic studies of Colocasia esculenta (L.) Schott (Araceae) and closely related taxa. Mol. Ecol. Resour. 13, 929-937. doi: 10.1111/ 1755-0998.12128

Akoglu, H. (2018). User's guide to correlation coefficients. Turkish J. Emerg. Med. 18, 91-93. doi: 10.1016/j.tjem.2018.08.001
Supplementary Figure 1 | Represent the non-normal distribution of SNPs, InDels, and repeats in Wolffia australiana.

Supplementary Figure 2 | Represent the non-normal distribution of SNPs, InDels, and repeats in Anthurium huixtlense.

Supplementary Figure 3 | Represent the non-normal distribution of SNPs, InDels, and repeats in Taccarum caudatum.

Supplementary Figure 4 | Represent the non-normal distribution of SNPs, InDels, and repeats in Aglaonema costatum.

Supplementary Table 1 | Distributions of substitutions, InDels, and oligonucleotide repeats in bins of $250 \mathrm{bp}$ in pairwise comparisons at family level.

Supplementary Table 2 | Distributions of substitutions, InDels, and oligonucleotide repeats in bins of $250 \mathrm{bp}$ in pairwise comparisons at subfamily level.

Supplementary Table 3 | Distributions of substitutions, InDels, and oligonucleotide repeats in bins of $250 \mathrm{bp}$ in pairwise comparisons at genus level.

Avni, A., and Edelman, M. (1991). Direct selection for paternal inheritance of chloroplasts in sexual progeny of Nicotiana. MGG Mol. Gen. Genet. 225, 273-277. doi: 10.1007/BF00269859

Boyce, P. C., and Croat, T. B. (2018). The Überlist of Araceae, Totals for Published and Estimated Number of Species in Aroid Genera. Aroid society. doi: 10.1007/ bf00269859

Chen, J.-Q., Wu, Y., Yang, H., Bergelson, J., Kreitman, M., and Tian, D. (2009). Variation in the ratio of nucleotide substitution and indel rates across genomes in mammals and bacteria. Mol. Biol. Evol. 26, 1523-1531. doi: 10.1093/molbev/ msp063

Choi, K. S., Park, K. T., and Park, S. (2017). The chloroplast genome of Symplocarpus renifolius: a comparison of chloroplast genome structure in Araceae. Genes 8:324. doi: 10.3390/genes8110324

Cusimano, N., Bogner, J., Mayo, S. J., Boyce, P. C., Wong, S. Y., Hesse, M., et al. (2011). Relationships within the Araceae: comparison of morphological patterns with molecular phylogenies. Am. J. Bot. 98, 654-668. doi: 10.3732/ajb. 1000158

Daniell, H., Lin, C.-S., Yu, M., and Chang, W.-J. (2016). Chloroplast genomes: diversity, evolution, and applications in genetic engineering. Genome Biol. 17:134. doi: 10.1186/s13059-016-1004-2

Han, L., Wang, B., and Wang, Z. Z. (2016). The complete chloroplast genome sequence of Spathiphyllum kochii. Mitochondrial. DNA 27, 2973-2974. doi: 10.3109/19401736.2015.1060466

Hardison, R. C., Roskin, K. M., Yang, S., Diekhans, M., Kent, W. J., Weber, R., et al. (2003). Covariation in frequencies of substitution, deletion, transposition, and recombination during eutherian evolution. Genome Res. 13, 13-26. doi: $10.1101 /$ gr.844103

Hart, S. P., Turcotte, M. M., and Levine, J. M. (2019). Effects of rapid evolution on species coexistence. Proc. Natl. Acad. Sci. U S A. 116, 2112-2117. doi: 10.1073/ pnas. 1816298116

Henriquez, C. L., Abdullah, Ahmed, I., Carlsen, M. M., Zuluaga, A., and Croat, T. B. (2020a). Evolutionary dynamics of chloroplast genomes in subfamily Aroideae (Araceae). Genomics 112, 2349-2360. doi: 10.1016/j.ygeno.2020.01.006

Henriquez, C. L., Abdullah, Ahmed, I., Carlsen, M. M., Zuluaga, A., and Croat, T. B. (2020b). Molecular evolution of chloroplast genomes in Monsteroideae (Araceae). Planta 251:72. doi: 10.1007/s00425-020-03365-7

Henriquez, C. L., Arias, T., Pires, J. C., Croat, T. B., and Schaal, B. A. (2014). Phylogenomics of the plant family Araceae. Mol. Phylogenet. Evol. 75, 91-102. doi: 10.1016/j.ympev.2014.02.017

Hu, S., Li, G., Yang, J., and Hou, H. (2017). Aquatic plant genomics: advances, applications, and prospects. Int. J. Genomics 2017, 1-9. doi: 10.1155/2017/ 6347874

Iram, S., Hayat, M. Q., Tahir, M., Gul, A., Abdullah, and Ahmed, I. (2019). Chloroplast genome sequence of Artemisia scoparia: comparative analyses and screening of mutational hotspots. Plants 8:476. doi: 10.3390/plants811 0476

Jheng, C.-F., Chen, T.-C., Lin, J.-Y., Chen, T.-C., Wu, W.-L., and Chang, C.C. (2012). The comparative chloroplast genomic analysis of photosynthetic 
orchids and developing DNA markers to distinguish Phalaenopsis orchids. Plant Sci. 190, 62-73. doi: 10.1016/j.plantsci.2012.04.001

Kawata, M., Harada, T., Shimamoto, Y., Oono, K., and Takaiwa, F. (1997). Short inverted repeats function as hotspots of intermolecular recombination giving rise to oligomers of deleted plastid DNAs (ptDNAs). Curr. Genet. 31, 179-184. doi: $10.1007 /$ s002940050193

Kearse, M., Moir, R., Wilson, A., Stones-Havas, S., Cheung, M., Sturrock, S., et al. (2012). Geneious basic: an integrated and extendable desktop software platform for the organization and analysis of sequence data. Bioinformatics 28 , 1647-1649. doi: 10.1093/bioinformatics/bts199

Kim, K.-J., and Lee, H.-L. (2005). Widespread occurrence of small inversions in the chloroplast genomes of land plants. Mol. Cells 19, 104-113.

Kim, S.-H., Yang, J., Park, J., Yamada, T., Maki, M., and Kim, S.-C. (2019). Comparison of whole plastome sequences between thermogenic skunk cabbage Symplocarpus renifolius and nonthermogenic S. nipponicus (Orontioideae; Araceae) in East Asia. Int. J. Mol. Sci. 20:4678. doi: 10.3390/ijms20194678

Kurtz, S., Choudhuri, J. V., Ohlebusch, E., Schleiermacher, C., Stoye, J., and Giegerich, R. (2001). REPuter: the manifold applications of repeat analysis on a genomic scale. Nucleic Acids Res. 29, 4633-4642. doi: 10.1093/nar/29.22.4633

Li, J., Su, Y., and Wang, T. (2018). The repeat sequences and elevated substitution rates of the chloroplast $a c c D$ Gene in Cupressophytes. Front. Plant Sci. 9:533. doi: 10.3389/fpls.2018.00533

Li, Y., Zhang, Z., Yang, J., and Lv, G. (2018). Complete chloroplast genome of seven Fritillaria species, variable DNA markers identification and phylogenetic relationships within the genus. PLoS One 13:e0194613. doi: 10.1371/journal. pone. 0194613

Li, L., Jiang, Y., Liu, Y., Niu, Z., Xue, Q., Liu, W., et al. (2020). The large single-copy (LSC) region functions as a highly effective and efficient molecular marker for accurate authentication of medicinal Dendrobium species. Acta Pharm. Sin. B 10, 1989-2001. doi: 10.1016/j.apsb.2020.01.012

Lockhart, P., Novis, P., Milligan, B. G., Riden, J., Rambaut, A., and Larkum, T. (2006). Heterotachy and tree building: a case study with plastids and eubacteria. Mol. Biol. Evol. 23, 40-45. doi: 10.1093/molbev/msj005

Lockhart, P. J., McLenachan, P. A., Havell, D., Glenny, D., Huson, D., and Jensen, U. (2001). Phylogeny, radiation, and transoceanic dispersal of New Zealand Alpine Buttercups: molecular evidence under split decomposition. Ann. Missouri Bot. Gard. 88:458. doi: 10.2307/3298586

Mayo, S. J., Bogner, J., Catherine, E., and Boyce, P. J. (1997). The Genera of Araceae. London: Royal Botanic Gardens, Kew.

McDonald, M. J., Wang, W. C., Huang, D-H.,, and Leu, J. Y. (2011). Clusters of nucleotide substitutions and insertion/deletion mutations are associated with repeat sequences. PLoS Biol. 9:e1000622. doi: 10.1371/journal.pbio.1000622

Mehmood, F., Abdullah, Shahzadi, I., Ahmed, I., Waheed, M. T., and Mirza, B. (2020a). Characterization of Withania somnifera chloroplast genome and its comparison with other selected species of Solanaceae. Genomics 112, 15221530. doi: 10.1016/j.ygeno.2019.08.024

Mehmood, F., Abdullah, Ubaid, Z., Bao, Y., and Poczai, P. (2020b). Comparative plastomics of ashwagandha (Withania, Solanaceae) and identification of mutational hotspots for barcoding medicinal plants. Plants 9:752. doi: 10.3390/ plants 9060752

Mehmood, F., Abdullah, Ubaid, Z., Shahzadi, I., Ahmed, I., and Waheed, M. T. (2020c). Plastid genomics of Nicotiana (Solanaceae): insights into molecular evolution, positive selection and the origin of the maternal genome of Aztec tobacco (Nicotiana rustica). PeerJ 8:e9552. doi: 10.1101/2020.01.13. 905158

Mes, T. H., Kuperus, P., Kirschner, J., Stepanek, J., Oosterveld, P., Storchova, H., et al. (2000). Hairpins involving both inverted and direct repeats are associated with homoplasious indels in non-coding chloroplast DNA of Taraxacum (Lactuceae: Asteraceae). Genome 43, 634-641. doi: 10.1139/g99-135

Nauheimer, L., Metzler, D., and Renner, S. S. (2012). Global history of the ancient monocot family Araceae inferred with models accounting for past continental positions and previous ranges based on fossils. New Phytol. 195, 938-950. doi: 10.1111/j.1469-8137.2012.04220.x

Neale, D. B., and Sederoff, R. R. (1989). Paternal inheritance of chloroplast DNA and maternal inheritance of mitochondrial DNA in Loblolly pine. Theor. Appl. Genet. 77, 212-216. doi: 10.1007/BF00266189

Palmer, J. D. (1985). Comparative organization of chloroplast genomes. Annu. Rev. Genet. 19, 325-354. doi: 10.1146/annurev.ge.19.120185.001545
Poczai, P., and Hyvönen, J. (2011). Identification and characterization of plastid trnF (GAA) pseudogenes in four species of Solanum (Solanaceae). Biotechnol. Lett. 33, 2317-2323. doi: 10.1007/s10529-011-0701-x

Poczai, P., and Hyvönen, J. (2017). The complete chloroplast genome sequence of the CAM epiphyte Spanish moss (Tillandsia usneoides, Bromeliaceae) and its comparative analysis. PLoS One 12:e0187199. doi: 10.1371/journal.pone. 0187199

Poczai, P., Hyvönen, J., and Symon, D. E. (2011). Phylogeny of kangaroo apples (Solanum subg. Archaesolanum, Solanaceae). Mol. Biol. Rep. 38, 5243-5259. doi: 10.1007/s11033-011-0675-8

Sablok, G., Amiryousefi, A., He, X., Hyvönen, J., and Poczai, P. (2019). Sequencing the plastid genome of giant ragweed (Ambrosia trifida, Asteraceae) from a herbarium specimen. Front. Plant Sci. 10:218. doi: 10.3389/fpls.2019. 00218

Shahzadi, I., Abdullah, Mehmood, F., Ali, Z., Ahmed, I., and Mirza, B. (2020). Chloroplast genome sequences of Artemisia maritima and Artemisia absinthium: comparative analyses, mutational hotspots in genus Artemisia and phylogeny in family Asteraceae. Genomics 112, 1454-1463. doi: 10.1016/J. YGENO.2019.08.016

Silva, J. C., and Kondrashov, A. S. (2002). Patterns in spontaneous mutation revealed by human-baboon sequence comparison. Trends Genet. 18, 544-547. doi: 10.1016/S0168-9525(02)02757-9

Tian, D., Wang, Q., Zhang, P., Araki, H., Yang, S., Kreitman, M., et al. (2008). Single-nucleotide mutation rate increases close to insertions/deletions in eukaryotes. Nature 455, 105-108. doi: 10.1038/nature07175

Wang, W., Chen, S., Guo, W., Li, Y., and Zhang, X. (2020). Tropical plants evolve faster than their temperate relatives: a case from the bamboos (Poaceae: Bambusoideae) based on chloroplast genome data. Biotechnol. Biotechnol. Equip. 34, 482-493. doi: 10.1080/13102818.2020.1773312

Whitlock, B. A., Hale, A. M., and Groff, P. A. (2010). Intraspecific inversions pose a challenge for the trnH-psbA Plant DNA Barcode. PLoS One 5:e11533. doi: 10.1371/journal.pone.0011533

Xu, J.-H., Liu, Q., Hu, W., Wang, T., Xue, Q., and Messing, J. (2015). Dynamics of chloroplast genomes in green plants. Genomics 106, 221-231. doi: 10.1016/J. YGENO.2015.07.004

Yang, H., Wu, Y., Feng, J., Yang, S., and Tian, D. (2009). Evolutionary pattern of protein architecture in mammal and fruit fly genomes. Genomics 93, 90-97. doi: 10.1016/j.ygeno.2008.09.009

Yi, X., Gao, L., Wang, B., Su, Y.-J., and Wang, T. (2013). The complete chloroplast genome sequence of Cephalotaxus oliveri (Cephalotaxaceae): evolutionary comparison of cephalotaxus chloroplast dnas and insights into the loss of inverted repeat copies in gymnosperms. Genome Biol. Evol. 5, 688-698. doi: 10.1093/gbe/evt042

Zhang, W., Sun, X., Yuan, H., Araki, H., Wang, J., and Tian, D. (2008). The pattern of insertion/deletion polymorphism in Arabidopsis thaliana. Mol. Genet. Genomics 280, 351-361. doi: 10.1007/s00438-008-0370-1

Zhu, A., Guo, W., Gupta, S., Fan, W., and Mower, J. P. (2016). Evolutionary dynamics of the plastid inverted repeat: the effects of expansion, contraction, and loss on substitution rates. New Phytol. 209, 1747-1756. doi: 10.1111/nph. 13743

Zhu, L., Wang, Q., Tang, P., Araki, H., and Tian, D. (2009). Genomewide association between Insertions/Deletions and the nucleotide diversity in bacteria. Mol. Biol. Evol. 26, 2353-2361. doi: 10.1093/molbev/msp144

Conflict of Interest: IA was employed by company Alpha Genomics Private Limited, Islamabad, Pakistan.

The remaining authors declare that the research was conducted in the absence of any commercial or financial relationships that could be construed as a potential conflict of interest.

Copyright $\odot 2021$ Abdullah, Henriquez, Croat, Poczai and Ahmed. This is an openaccess article distributed under the terms of the Creative Commons Attribution License (CC BY). The use, distribution or reproduction in other forums is permitted, provided the original author(s) and the copyright owner(s) are credited and that the original publication in this journal is cited, in accordance with accepted academic practice. No use, distribution or reproduction is permitted which does not comply with these terms. 